\title{
A pilot clinical study to evaluate the effectiveness of olive extract containing hydroxytyrosol for oral and topical treatment of melasma
}

\author{
Estudo clínico piloto para avaliar a eficácia do extrato de oliva contendo hidroxitirosol para \\ tratamento oral e tópico do melasma
}

\author{
Julia de Toledo Bagatin ${ }^{1}$, Ediléia Bagatin ${ }^{2}$, Patrícia Maria Berardo Gonçalves Maia Campos ${ }^{1 *}$ \\ ${ }^{1}$ School of Pharmaceutical Sciences of Ribeirão Preto - University of São Paulo, Avenida do Café, S/N, \\ Ribeirão Preto - SP, 14040-903; ${ }^{2}$ Dermatology Department - Medical School - Federal University of São Paulo, \\ R. Borges Lagoa, 508 - Vila Clementino, São Paulo - SP, 04038-001 \\ *Corresponding author: pmcampos@usp.br
}

\begin{abstract}
Melasma is a common hyperpigmentation that can cause impairment of quality of life. Current melasma treatments present limitations and adjuvant treatments are of great interest.. The objective of this study was to evaluate the clinical efficacy of an oral and topical treatment based on olive extract containing hydroxytyrosol for melasma control. A pilot clinical study was conducted with 42 women with melasma, randomized in three groups of 14 participants - control, oral or topical, who received daily treatment containing hydroxytyrosol or placebo for 90 days. Melasma was evaluated once a month using the melasma area and severity index (mMASI) and the melanin and erythema index. Statistical analysis was performed using ANOVA between the groups and paired ANOVA (RM) in each group individually. The melanin index and mMASI resulted in reduced values for oral treatment, compared to the control and topical group with no significant difference $(\mathrm{p}>0.05)$. However, oral treatment evaluated paired by time showed a significant reduction in mMASI $(\mathrm{p}<0.0001)$ and melanin index $(\mathrm{p}=0.0466)$ after 60 days. Finally, the treatments with olive extract based on hydroxytyrosol showed great potential for the control of melasma or as an adjunctive to traditional dermatological treatment.
\end{abstract}

Keywords: Hydroxytyrosol, olive extracts, depigmentation agents, clinical trial, melasma

\begin{abstract}
Resumo
O melasma é uma das hiperpigmentações adquiridas mais comuns e pode causar prejuízos na qualidade de vida. Os tratamentos apresentam limitações e, portanto, tratamentos auxiliares para o controle do melasma são de grande interesse. O objetivo do estudo foi avaliar a eficácia clínica de tratamentos oral e tópico à base de extrato de oliva contendo hidroxitirosol para o controle do melasma. Foi realizado um estudo clínico piloto com 42 mulheres com melasma randomizadas em três grupos com 14 participantes - controle, oral ou tópico - que receberam tratamento diário com hidroxitirosol ou placebo por 90 dias. O melasma foi avaliado mensalmente utilizando os índices de área e gravidade do melasma (mMASI) e de melanina e eritema. A análise estatística foi realizada usando ANOVA entre os grupos e ANOVA $\mathrm{RM}$ em cada grupo individualmente. $\mathrm{O}$ índice de melanina e eritema e mMASI resultaram em valores menores para o tratamento oral comparado com os grupos controle e tópico. No entanto, o tratamento oral reduziu significativamente os valores do índice mMASI $(\mathrm{p}=0,0132)$ e melanina $(\mathrm{p}=0.047)$ após 60 dias. Por fim, os tratamentos com extrato de oliva baseado em hidroxitirosol mostraram grande potencial para o controle do melasma ou como adjuvante ao tratamento convencional.
\end{abstract}

Palavras-chave: Hidroxitirosol, extrato de oliva, agentes despigmentantes, estudo clínico, melasma 


\section{Introduction}

Melasma is a common acquired chronic hyperpigmentation affecting mostly the face, characterized by brown patches of variable darkness. Melasma affects all racial types with variable incidence but is more common in women of skin phototypes III to $\mathrm{V}$ and residing in areas with high ultraviolet radiation incidence $(1,2)$ The exact cause of melasma is still unknown but it is considered to have a heterogeneous pathology involving multiple factors. Exposure to sunlight, family history, and hormonal alterations are the main triggering factors (3). Although it is an aesthetical asymptomatic disorder, melasma can cause significant psychosocial discomfort, impairing quality of life and leading to high therapeutic demand (4).

Diverse treatment options are available, including topical and oral agents, chemical peelings and laser administration. Therapy remains a challenge, however, as results are highly variable, unpredictable, inconsistent, and associated with frequent relapses and adverse effects (5). Topical treatment is still the main modality of treatment for hyperpigmentation conditions, including melasma.

Despite the multifactorial mechanism involved in the development of melasma, inhibition of melanogenesis by topical treatment is the main target of depigmenting agents. The standard depigmenting agent is hydroquinone, but its safety is controversial due to cases of exogenous ochronosis and other adverse events (6). Therefore, alternative tyrosinase inhibitors representing safer and more effective depigmenting agents for melasma are of great demand $(7,8)$.

Tyrosinase is an enzyme that catalyze the first two main steps of melanin biosynthesis, which L-tyrosine is hydroxylated to L- dihydroxyphenylalanine (L-DOPA) and sequentially oxidated to dopaquinone $(8,9)$.

Dihydroxyphenols, such as hydroquinone and hydroxytyrosol, represents a known group of antioxidant molecules that inhibit tyrosinase as competitive substrates L- DOPA, generating enzymatic reaction products that do not undergo the next steps of melanogenesis $(8,10)$. However, hydroxytyrosol has the advantage to be considered non-cytotoxic and non-mutagenic according to experiments in animal models (11).

Hydroxytyrosol (3,4-dihydroxiphenylethanol) is the main antioxidant phenol found in olive extracts. In vitro studies have demonstrated it has diverse pharmacological effects (antioxidant, anti-inflammatory, anti-cancer and neuro-protective (12)) and could also be beneficial to the adjunctive treatment of melasma. Hydroxytyrosol is a very potent antioxidant, with higher antioxi-

\section{Introdução}

Melasma é uma hiperpigmentação crônica adquirida comum que afeta principalmente a face, caracterizada por manchas marrons de escuridão variável. Melasma afeta todos os tipos raciais com incidência variável, mas é mais comum em mulheres, fototipos III a $\mathrm{V}$ e residentes em áreas com alta incidência de radiação ultravioleta $(1,2)$. A causa exata do melasma ainda é desconhecida, mas é considerada uma patologia heterogênea por envolver múltiplos fatores. A exposição ao sol, o histórico familiar e as alterações hormonais são os principais fatores desencadeantes (3).

Embora seja um distúrbio estético assintomático, o melasma pode causar desconforto psicossocial significativo, prejudicando a qualidade de vida e levando à alta demanda terapêutica (4).

Diversas opções de tratamento estão disponíveis, incluindo agentes tópicos e orais, peelings químicos e laser. Mas a terapia continua a ser um desafio, pois os resultados são altamente variáveis, imprevisíveis e inconsistentes, associados a frequentes recaídas e efeitos adversos (5). O tratamento tópico ainda é a principal modalidade de tratamento para condições hiperpigmentares, incluindo o melasma.

Apesar do mecanismo multifatorial envolvido no desenvolvimento do melasma, a inibição da melanogênese pelo tratamento tópico é o principal alvo dos agentes despigmentantes. $\mathrm{O}$ agente despigmentante padrão é a hidroquinona, mas sua segurança é controversa devido a casos de ocronose exógena e outros eventos adversos (6). A hidroquinona atua como um inibidor da tirosinase; no entanto, inibidores da tirosinase mais seguros e eficazes para atuar como agentes despigmentantes do melasma são de grande demanda $(7,8)$.

A tirosinase é uma enzima que catalisa os dois primeiros passos principais da biossíntese da melanina, cuja L-tirosina é hidroxilada em L-di-hidroxifenilalanina (L-DOPA) e sequencialmente oxidada em dopaquinona $(8,9)$.

Os diidroxifenóis, como hidroquinona e hidroxitirosol, representam um conhecido grupo de moléculas antioxidantes que inibem a tirosinase como substratos competitivos à L-DOPA, gerando produtos de reações enzimáticas que não passam pelos próximos passos da melanogênese $(8,10)$. Além disso, o hidroxitirosol tem a vantagem de ser considerado não citotóxico ou mutagênico por experimentos em modelos animais (11). O hidroxitirosol (3,4-dihidroxifeniletanol) é o principal fenol antioxidante encontrado nos extratos de oliva. Estudos in vitro demonstraram diversos efeitos farmacológicos como atividade antioxidante, antiin- 
dant activity than ascorbic acid (13), a well-known but unstable ingredient for melasma treatment that exerts its depigmenting action by strong antioxidant activity (14). Another in vitro study with hydroxytyrosol reported that the dose-dependent inhibition of tyrosinase was comparable to another depigmenting agent, kojic acid (21). In fact, hydroxytyrosol has a potent radical scavenging activity and can protect UV-derived oxidative stress cytotoxicity to keratinocytes $(22,22,24)$.

In addition, in vitro studies have shown that hydroxytyrosol has an anti-inflammatory potential to inhibit matrix metalloproteinase-9 (MMP-9) gene expression (16). This is one of the metalloproteins responsible for basal membrane impairment in a microenvironment of cutaneous photoaging (18), an attribute of melasma's pathology $(5,6)$.

In this context, olive extracts containing hydroxytyrosol presents potential pharmacological effects as a safe botanical dermatological alternative in topical and oral treatment for melasma control or as an adjunctive longterm maintenance treatment.

The aim of the study was to evaluate the clinical efficacy of an oral and topical treatment based on olive extract containing hydroxytyrosol for melasma control.

\section{Material and Methods}

A randomized, double-blind, placebo-controlled, pilot study was conducted with a convenience sample of 42 women for 90 days at the School of Pharmaceutical Sciences of Ribeirao Preto - Universidade de São Paulo (FCFRP-USP), Ribeirao Preto - SP, Brazil. The study protocol was previously approved by the institutional Ethical Commission for Research (CEP/FCFRP $\left.\mathrm{n}^{\mathrm{o}} 4346115.0 .00005403\right)$. The study was performed from January 2017 to October 2017. Informed written consent was obtained from all subjects prior to enrollment. Inclusion criteria were being women, age 30-50, Fitzpatrick phototypes III and IV (18), presenting center-facial melasma. Patients were screened by telephone and, if eligible, underwent a screening examination by the investigators at the university. Non-inclusion criteria were pregnancy, history of adverse reaction to cosmetics, systemic diseases, and use of skin-whitening treatments three months prior to inclusion in the study. At the initial visit, a pre-structured interview was con- flamatória, supressora tumoral e neuro-protetora $(12$, 15), e também poderiam ser benéficos ao tratamento adjuvante do melasma. O hidroxitirosol é um antioxidante potente, sua atividade antioxidante é mais efetiva que o ácido ascórbico (13), um ingrediente renomado, mas instável para o tratamento do melasma que exerce sua ação despigmentante pela forte atividade antioxidante (14). Outro estudo in vitro com hidroxitirosol relatou que a inibição da tirosinase é dependente da dose e comparável ao ácido kójico, outro ingrediente ativo usado como agente despigmentante (21). De fato, o hidroxitirosol tem uma atividade de eliminação de radicais livres potente e pode proteger a citotoxicidade gerada pelo estresse oxidativo derivado do UV em queratinócitos $(22,23,24)$.

Além disso, estudos in vitro evidenciaram que o hidroxitirosol tem o potencial anti-inflamatório para inibir a expressão do gene metaloproteinase de matriz-9 (MMP-9) (16). Esta é uma das metaloproteínas responsáveis pelo comprometimento da membrana basal em um microambiente do fotoenvelhecimento cutâneo (17), uma característica presente na patologia do melasma $(5,6)$.

Nesse contexto, o extrato de oliva contendo hidroxitirosol apresentam potenciais efeitos farmacológicos como uma alternativa de origem botânica segura para o tratamento tópico e oral no controle do melasma ou como um tratamento de manutenção a longo prazo. Assim, o objetivo do estudo foi avaliar a eficácia clínica de um tratamento oral e tópico à base de extrato de oliva contendo hidroxitirosol para o controle do melasma.

\section{Materiais e Métodos}

Foi realizado um estudo clínico piloto randomizado, duplo-cego, placebo-controlado, com uma amostra de conveniência definida com 42 mulheres durante 90 dias na Faculdade de Ciências Farmacêuticas de Ribeirão Preto - Universidade de São Paulo (FCFRPUSP), Ribeirão Preto - SP, Brasil. O protocolo do estudo foi aprovado pelo Comitê de Ética em Pesquisa (CEP / FCFRP nº4346115.0.00005403). O estudo foi realizado de janeiro de 2017 a outubro de 2017 . O termo de consentimento livre e esclarecido foi assinado pelas participantes antes de sua inscrição. Os critérios de inclusão foram: mulheres, idade 30-50, Fitzpatrick Fototipos III e IV (18) apresentando melasma centrofacial. As pacientes foram selecionadas por telefone e, se elegíveis, foram submetidas a um exame de triagem pelos pesquisadores da universidade. Os critérios de não inclusão foram gravidez, história de reação adversa a cosméticos, doenças sistêmicas, uso de tratamentos 


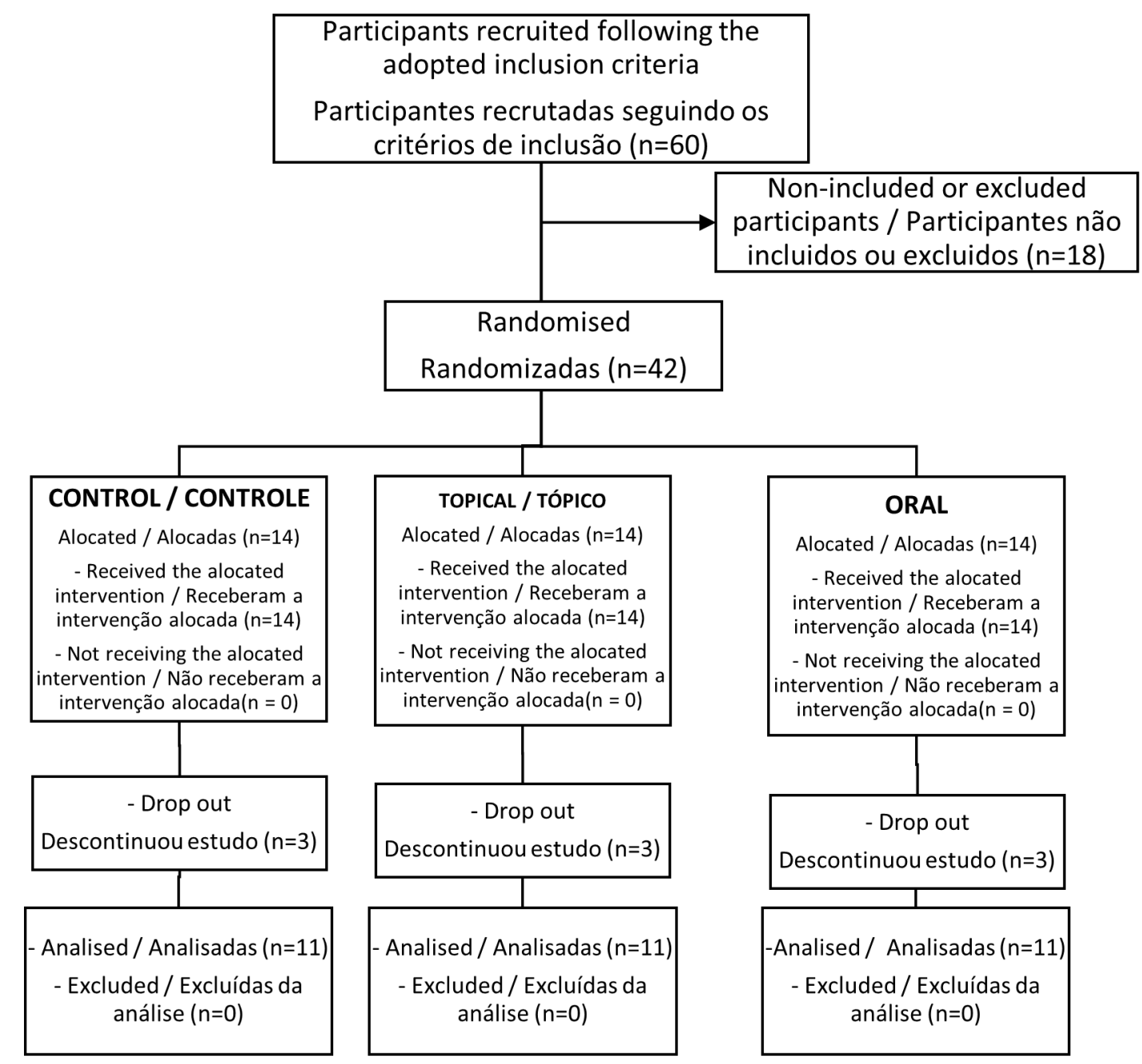

Figure 1 - Flow diagram according to CONSORT guidelines showing the flow of participants in the trial, including dropouts

Figura 1 - Diagrama de fluxo de acordo com as diretrizes do CONSORT mostrando o fluxo de participantes no estudo, incluindo desistências

ducted to obtain personal information about influencing or exacerbating factors, including the time of onset of the melasma, subjective factor associated to its development, history of pregnancy, use of contraceptive pill, sun exposure, drug history, previous treatments for melasma and family history of melasma.

Figure 1 shows the flow diagram according to $\mathrm{CON}$ SORT guidelines showing the flow of participants in the study, including dropouts.

A statistic software (19) for randomization assignment in block design divided the subjects in three groups with 14 participants each that received the interventions as described: de clareamento da pele 3 meses antes da inclusão no estudo.

$\mathrm{Na}$ visita inicial, foi realizada uma entrevista pré-estruturada para obter informações pessoais sobre fatores que influenciam ou exacerbam a doença, incluindo o tempo de início do melasma, fator subjetivo associado ao seu desenvolvimento, história de gravidez, uso de pílula anticoncepcional, exposição ao sol, histórico medicamentoso, tratamentos prévios para o melasma e história familiar.

A Figura 1 mostra o diagrama de fluxo de acordo com as diretrizes do CONSORT mostrando o fluxo de participantes no estudo, incluindo desistências.

Um software estatístico (19) para a randomização em blocos dividiu as participantes em três grupos com 14 participantes, que receberam as intervenções descritas a seguir: 
- Control: topical vehicle formulation and oral placebo

- Topical: topical formulation containing the olive extract and oral placebo

- Oral: topical vehicle formulation and oral capsule containing the olive extract

The topical formulation was based on an emulsion composed by (INCI - International Nomenclature Cosmetic Ingredient): Water, Carbomer, Caprylic capric triglyceride, Ceteareth - 20, Cetyl Alcohol, C12-C15 Alkyl Benzoate, Butylene Glycol, Glycerin, Dimethicone Cyclopentasiloxane, Phenoxyethanol, Polysorbate 80, Butylated hydroxytoluene, Dissodium EDTA. This topical formulation was added or not (vehicle) with $1 \%$ of olive extract, which contains $20 \%$ hydroxytyrosol (HydrOlive $^{\circledR}$, Cobiosa, Spain). Oral supplementation consisted of capsules containing $300 \mathrm{mg}$ of olive extract containing 3\% hydroxytyrosol $\left(\mathrm{Oli}-\mathrm{Ola}^{\circledR}\right.$, Nexira Health, France) or placebo.

Participants were advised to use the products and sunscreen daily for 90 days. All participants used the same sunscreen. The study was designed as a double blind study, with neither the investigator nor the patients aware of the treatment content.

Clinical evaluations were performed before treatment (baseline), and 30, 60 and 90 days after the initiation of treatment.

The subjective evaluation of melasma was obtained by modified Melasma Area and Severity Index (mMASI) score (20), based on high resolution images of the face at standard positions and luminosity using Visioface 1000D equipment (Courage-Khazaka Electronic, Köln, Germany). The score was calculated by dividing the face into four areas: forehead (F), right malar (RM), left malar (LM), and chin (C), which correspond to $30 \%, 30 \%, 30 \%$, and $10 \%$ of the total face area, respectively. The melasma in each area was graded on two variables - area and darkness - that were scored as follows: area of involvement: $0=$ absent, $1=$ up to $10 \%, 2=10 \%-29 \%, 3=30 \%-49 \%, 4=50 \%-69 \%, 5=$ 70\%-89\%, and $6=90 \%-100 \%$; darkness: $0=$ absent, 1 $=$ slight, $2=$ mild, $3=$ marked, and $4=$ severe. The total score was calculated (mMASI $=0.3 \mathrm{~A}(\mathrm{f}) \mathrm{P}(\mathrm{f})+0.3 \mathrm{~A}$ (md) $\mathrm{P}(\mathrm{md})+0.3 \mathrm{~A}(\mathrm{me}) \mathrm{P}(\mathrm{me})+0.1 \mathrm{~A}(\mathrm{q}) \mathrm{P}(\mathrm{q})$ ) and ranged from 0 to 24 .

The skin pigmentation evaluation was obtained through a narrow band reflectance spectrophotometer Mexameter (Courage-Khazaka Electronic, Köln, Germany), which provided objective measurements from the lesional region of melanin and hemoglobin (erythema) indexes.

The experimental continuous data obtained in mMASI and Mexameter readings were evaluated using analysis
- Controle: formulação tópica de veículo e placebo oral.

- Tópica: formulação tópica contendo o extrato de oliva e placebo oral.

- Oral: formulação tópica de veículo e oral contendo o extrato de oliva.

A formulação tópica foi uma emulsão à base de (INCI International Nomenclature Cosmetic Ingredient): Water, Carbomer, Caprylic capric triglyceride, Ceteareth 20, Cetyl Alcohol, C12-C15 Alkyl Benzoate, Butylene Glycol, Glycerin, Dimethicone, Cyclopentasiloxane, Phenoxyethanol, Polysorbate 80, Butylated hydroxytoluene, Dissodium EDTA, acrescida ou não (veículo) de $1 \%$ de extrato de oliva, contendo $20 \%$ hidroxitirosol (HydrOlive ${ }^{\circledR}$, Cobiosa, Espanha). A suplementação oral foi feita com cápsulas contendo $300 \mathrm{mg}$ de extrato de oliva contendo $3 \%$ de hidroxitirosol, Oli-Ola ${ }^{\circledR}$, Nexira Health, França, ou placebo. As participantes do estudo foram orientadas a utilizar os produtos e o protetor solar diariamente por um período de 90 dias. Todas as participantes usaram o mesmo protetor solar. Nem o investigador nem os pacientes estavam cientes do conteúdo dos tratamentos - estudo duplo cego.

As avaliações clínicas foram realizadas antes - valores basais e após o período de 30,60 e 90 dias de tratamento.

A avaliação do melasma foi realizada por meio do escore modificado Melasma Area and Severity Index (mMASI) (20), baseado em imagens de alta resolução da face em posições e luminosidade padronizados pelo equipamento Visioface 1000D (Courage-Khazaka Electronic, Köln, Alemanha). A pontuação foi calculada dividindo a face em quatro áreas: testa $(\mathrm{F})$, malar direito (MD), malar esquerdo (ME) e queixo (Q), que correspondem a $30 \%, 30 \%, 30 \%$ e $10 \%$ da área total da face, respectivamente. O melasma em cada área foi classificado em duas variáveis - área e escuridão, que foram classificadas da seguinte forma: área de envolvimento: $0=$ ausente, $1=$ até $10 \%, 2=10 \%-29 \%, 3=$ $30 \%-49 \%, 4=50 \%-69 \%, 5=70 \%-89 \%$ e $6=90 \%$ $-100 \%$; Escuridão: $0=$ ausente, $1=$ leve, $2=$ leve, 3 $=$ marcado e $4=$ grave. $\mathrm{O}$ escore total foi calculado $(\mathrm{mMASI}=0,3 \mathrm{~A}(\mathrm{f}) \mathrm{P}(\mathrm{f})+0,3 \mathrm{~A}(\mathrm{md}) \mathrm{P}(\mathrm{md})+0,3 \mathrm{~A}$ (me) P (me) + 0,1A (q) P (q)) e varia de 0 a 24.

$A$ avaliação da pele por medidas objetivas de pigmentação na região lesionada foram determinadas com um espectrofotômetro de refletância de banda estreita Mexameter (Courage-Khazaka Electronic, Köln, Alemanha) fornecendo o índice de melanina e hemoglobina (eritema).

Os dados experimentais contínuos obtidos nas leituras de mMASI e Mexameter foram avaliados por meio de análise de variância (ANOVA), uma vez que os dados foram distribuídos normalmente pelo teste de normali- 
of variance (ANOVA), as the data was found to be normally distributed by the Shappiro-Wilk normality test (mMASI $p=0.182$; Mexameter $p=0.110$ ). A $p$ value $<0.05$ was assumed to indicate statistical significance for the comparison of the groups at four times: basal (t0), 30 (t30), 60 (t60) and 90 days (t90). Also, ANOVA with repeated measures (RM) was used to evaluate each treatment as single-arm to observe significative improvement comparing baseline values to 90 days. The statistical data was analyzed using GraphPad Prism software (GraphPad Software, California, USA), alpha set at 0.05 .

\section{Results}

After evaluating 60 participants screened by telephone, 42 met the inclusion criteria and were randomized into the four treatment groups with 14 allocated to each one: control, topical and oral. Three subjects in each studied group dropped out without any specific reason. The data from these patients were not considered in the objective efficacy analysis.

The baseline characteristics of the participants are summarized in Table 1. The age of the participants ranged from 32 to 49 years, with a mean of $40.5 \pm 4.3$ years. Overall, 29 (69\%) participants had Fitzpatrick phototype III and 13 (31\%) phototype IV. Moreover, the informed duration of melasma was distributed as follows: $17(40 \%)$ more than 10 years, $11(26 \%)$ from 6 to 10 years, 11 (26\%) for up to 5 years, $3(8 \%)$ no information, and, none $(0 \%)$ for less than 1 year.

Furthermore, the triggering factors associated with the development of melasma in participant's opinions $(n=42)$ were as follows: $17(40 \%)$ pregnancy, $5(12 \%)$ hormonal therapy, $8(19 \%)$ solar radiation, $3(8 \%)$ psychologic distress, 1 (2\%) cosmetic use, and $8(19 \%)$ reported no association to any specific cause. Pregnancy occurred in $34(80 \%)$ of cases, and gestation associated melasma was reported by $17(50 \%)$ of these patients. Thirty five (83\%) had used oral contraceptives, and 30 (71\%) had previously tried dermatological treatment.

Results obtained for facial pigmentation evaluated by mMASI were considered normal by the ShappiroWilk tests for treatment and time variables $(p>0.05)$. The mMASI presented great intervariability between groups as a result of intrinsic melasma characteristics. The facial pigmentation evaluated by mMASI showed no significant differences at the beginning of the study, as well as in its sequence at 30,60 and 90 days ( $p>0.05$, in each time evaluated). In contrast, significant results dade de Shappiro-Wilk (mMASI $\mathrm{p}=0,182$; Mexameter $\mathrm{p}=0,110)$. Em seguida, considerou-se um valor de $\mathrm{P}$ $<0,05$ para indicar significância estatística para a comparação dos grupos em quatro momentos: basal (t0), 30 (t30), 60 (t60) e 90 dias (t90). Além disso, ANOVA com medidas repetidas (RM) foi usado para avaliar cada tratamento como braço único para observar uma melhora significativa de cada tratamento individualmente comparando os valores basais aos 90 dias. Os dados estatísticos foram analisados utilizando o software GraphPad Prism (GraphPad Software - Califórnia, EUA), alfa a 0,05.

\section{Resultados}

Após avaliação de 60 participantes selecionadas por telefone, 42 preencheram os critérios de inclusão e foram randomizadas para os quatro grupos de tratamento com 14 alocadas para cada um: controle, tópico e oral. Três participantes em cada grupo estudado desistiram sem qualquer razão específica. Os dados desses pacientes não foram considerados na análise objetiva da eficácia. As características basais dos participantes estão resumidas na Tabela 1. A idade dos participantes variou de 32 a 49 anos, com média de 40,5 \pm 4,3 anos. No geral, 29 (69\%) participantes apresentaram o fototipo III de Fitzpatrick e 13 (31\%) o fototipo IV. A duração informada do melasma foi: $17(40 \%)$ mais de 10 anos, 11 $(26 \%)$ de 6 a 10 anos, $11(26 \%)$ até 5 anos, $3(8 \%)$ sem informação e, nenhuma por menos de 1 ano.

Além disso, os fatores desencadeantes associados ao desenvolvimento do melasma na opinião das participantes $(n=42)$ foram: $17(40 \%)$ gestação, $5(12 \%)$ terapia hormonal, $8(19 \%)$ radiação solar, $3(8 \%)$ psicológica angústia, $1(2 \%)$ uso cosmético e $8(19 \%)$ relataram nenhuma associação a qualquer causa específica. Gravidez havia ocorrido em 34 (80\%) dos casos, e o melasma associado à gestação foi relatado por $17(50 \%)$ dessas pacientes. Trinta e cinco (83\%) haviam usado contraceptivos orais e $30(71 \%)$ haviam realizado tratamento dermatológico anteriormente.

Os resultados obtidos para a pigmentação facial avaliada pelo mMASI foram consideradas normais pelos testes de Shappiro-Wilk nas variáveis tratamento e tempo $(\mathrm{p}>0,05)$. O mMASI apresentou grande intervariabilidade entre os grupos em decorrência das características intrínsecas do melasma. Os valores de pigmentação facial avaliados pelo mMASI não apresentaram diferenças significativas no início do estudo, assim como em sua sequência, aos 30, 60 e 90 dias (ANOVA $\mathrm{p}>0,05$, em cada tempo avaliado). 
Table 1 - Baseline characteristics of patients and melasma (SD standard deviation)

Tabela 1 - Características basais das participantes e do melasma por grupo (DP desvio padrão)

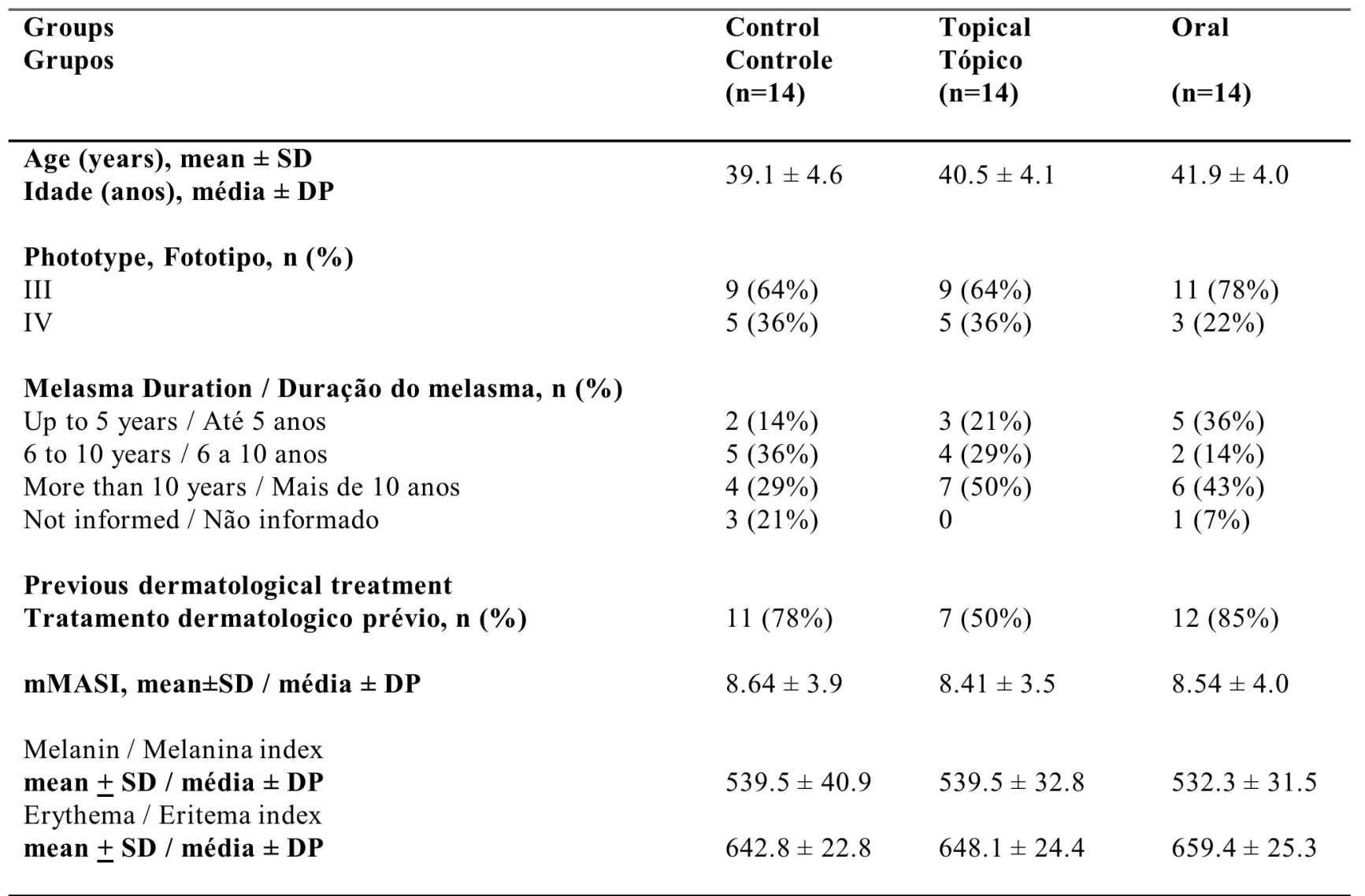

were detected in the mMASI when the treatments were analyzed as a single-arm with paired values for the time variation (ANOVA RM, p <0.0001), and by multiple comparisons, with Bonferroni correction, we verified this result refers to the oral group comparing baseline time to $60(\mathrm{p}=0.0212)$ and 90 days $(\mathrm{p}=0.0008)$, and to the topical group, which also showed improvement comparing the baseline time with 90 days $(p=0.0003)$. Nevertheless, a decrease of the score was observed for all groups during the treatment, especially for oral therapy, which presented a $22 \%$ decrease, compared to $11 \%$ for control group, and $15 \%$ for topical treatment (Figure 2).

Figures 3, 4 and 5 show high resolution images from the study participants as examples as illustration of results before and after treatments.

After confirming the normal distribution of data obtained for time and treatments (Shappiro-Wilk, $\mathrm{p}>$ $0.05)$, the melanin index measured by the Mexameter showed a slight decrease in pigmentation in the oral group. Even so, the results of the melanin index did not show significant reduction between the groups at all evaluated times (ANOVA, $\mathrm{p}>0.05$ ), as was observed
Por outro lado, resultados significativos foram detectados no mMASI quando os tratamentos foram analisados individualmente com valores pareados para a variação de tempo (ANOVA RM, $p<0,0001$ ), e pelas comparações múltiplas, com correção de Bonferroni, verificamos que este resultado se refere ao grupo oral na comparação entre o tempo inicial comparado a 60 $(\mathrm{p}=0,0212)$ e 90 dias ( $\mathrm{p}=0,0008)$, e ao grupo tópico, que também apresentou melhora comparando o tempo basal com o de 90 dias $(p=0,0003)$. No entanto, observouse diminuição do escore em todos os grupos durante o tratamento, especialmente para o tratamento oral, que apresentou redução de $22 \%$, comparado a $11 \%$ no grupo controle e $15 \%$ no tratamento tópico (Figure 2).

As Figuras 3, 4 e 5 ilustram as imagens de alta resolução obtidas de participantes do estudo, antes e após os tratamentos.

Após verificar a distribuição normal dos dados obtidos para tempo e tratamentos (Shappiro-Wilk, $p>0,05$ ), o índice de melanina medido pelo aparelho Mexameter apresentou leve diminuição da pigmentação no grupo oral. Mesmo assim, os resultados dos índices de melanina não apresentaram redução significativas entre os grupos 


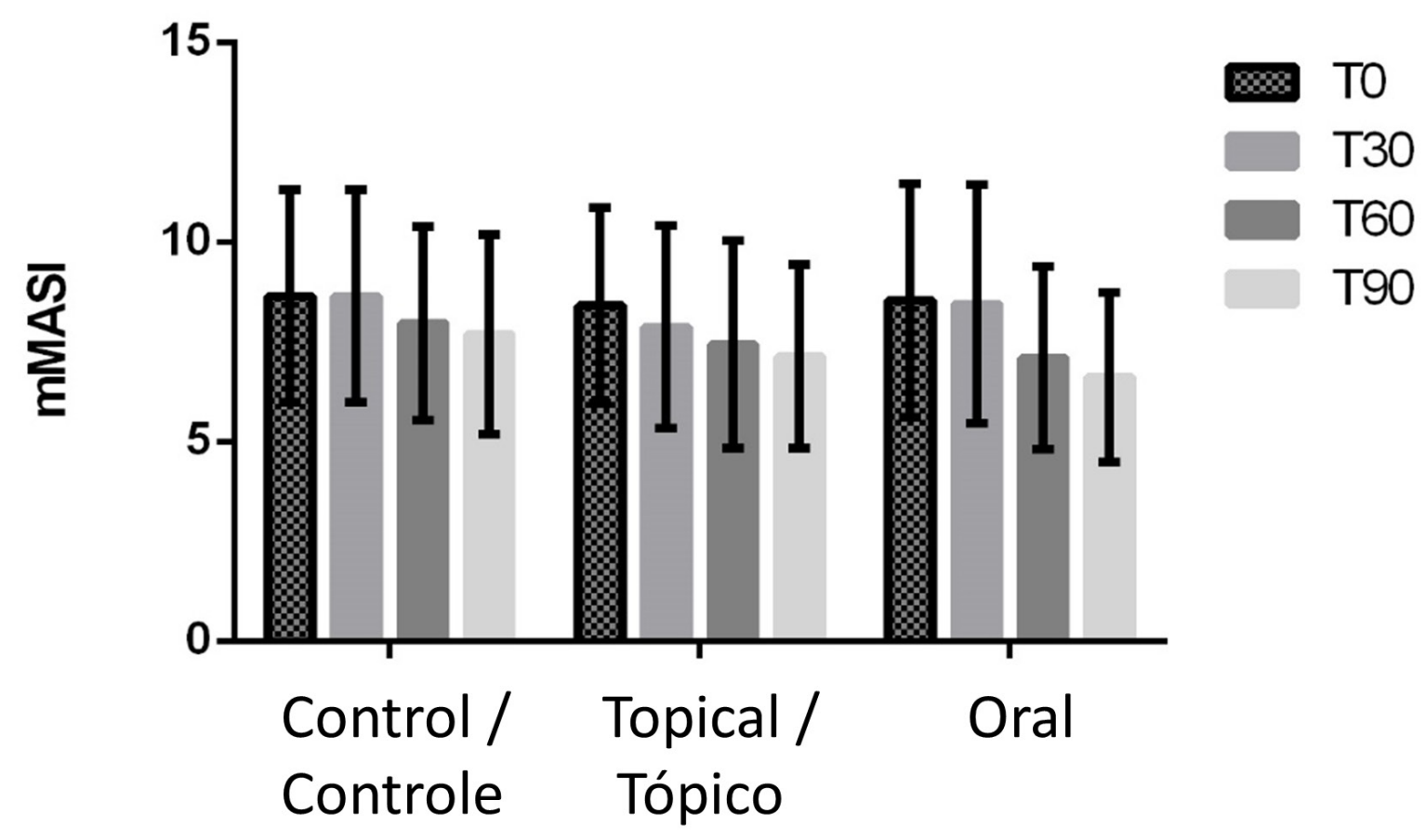

Figure 2 - mMASI values among treatment groups at evaluated times (means and confidence intervals CI95\% are indicated)

Figura 2 -Valores do mMASI entre os grupos de tratamento nos tempos avaliados ( são mostrados médias e intervalos de confiança IC95\%)

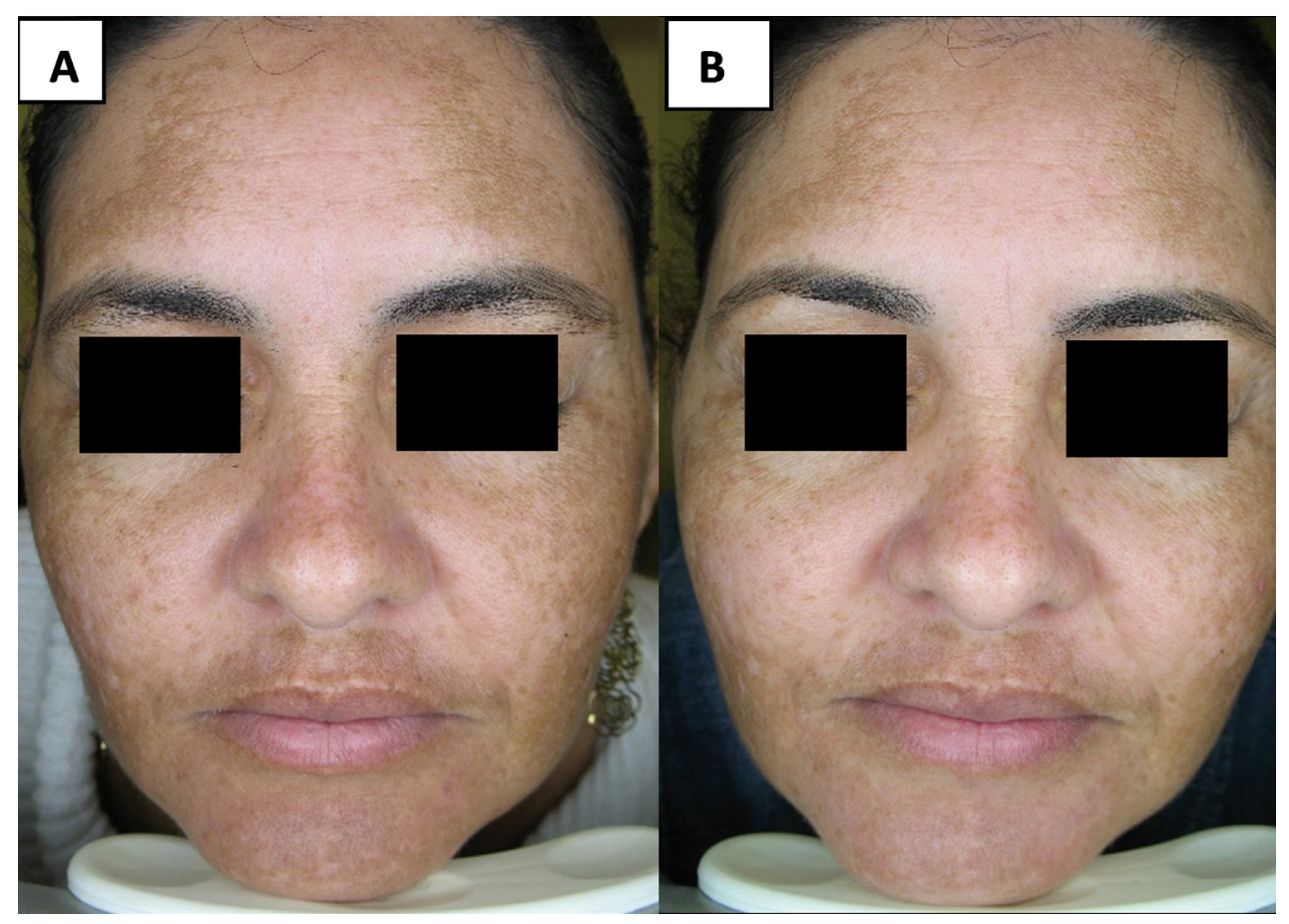

Figure 3 - A 41 year-old woman with recalcitrant melasma for 8 years before treatment (A) and after (B) 60 days of use of the topical treatment containing the olive extract

Figura 3 - Participante de 41 anos com melasma recalcitrante há 8 anos antes do tratamento (A) e após (B) 60 dias de uso do tratamento tópico contendo o extrato de oliva 


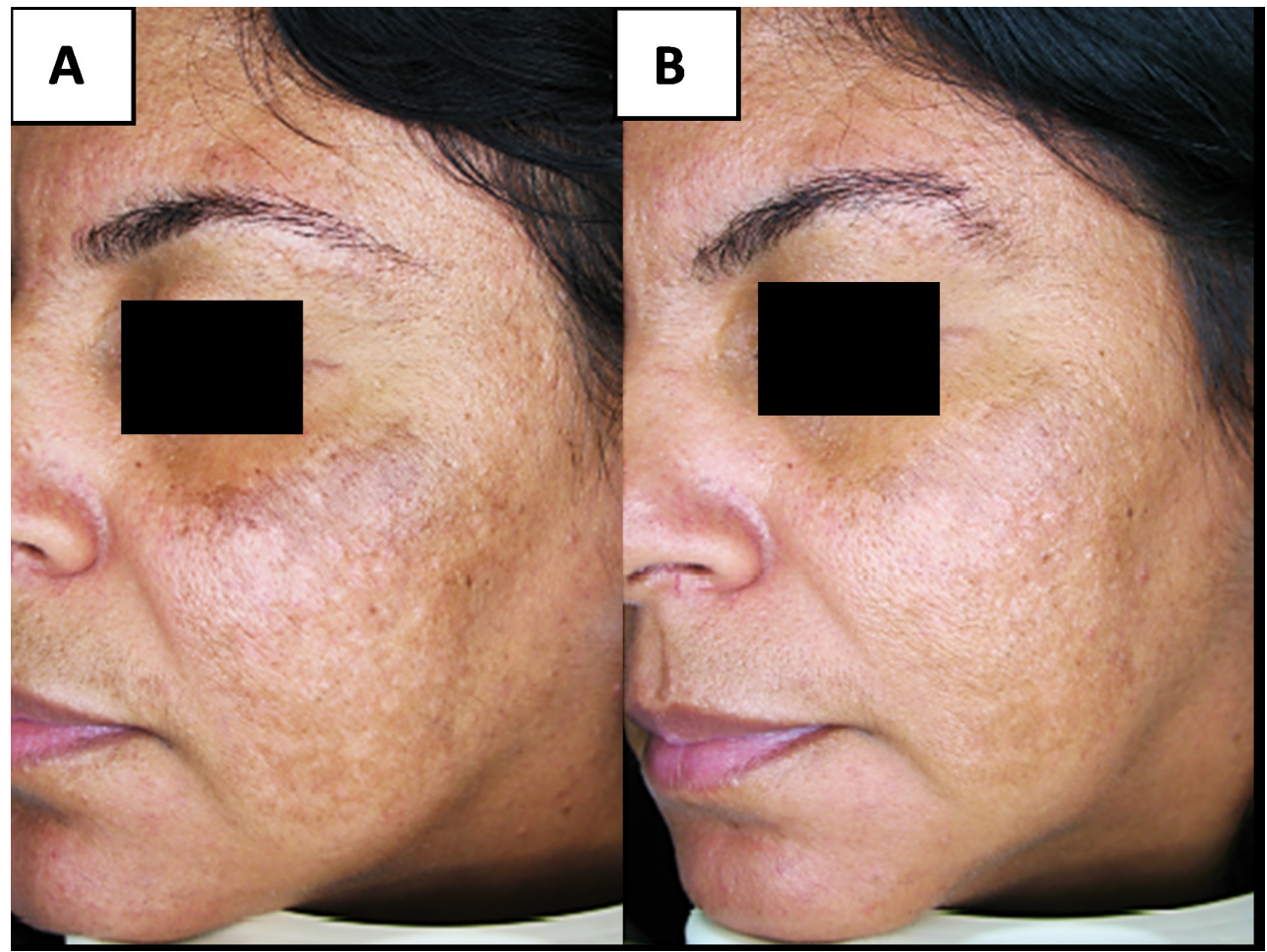

Figure 4 - A 36-year old woman with recalcitrant melasma for 19 years before treatment (A) and after (B) 60 days of use of the oral treatment containing the olive extract

Figura 4 - Participante de 36 anos com melasma recalcitrante há 19 anos antes do tratamento (A) e após (B) 60 dias de uso do tratamento oral contendo o extrato de oliva

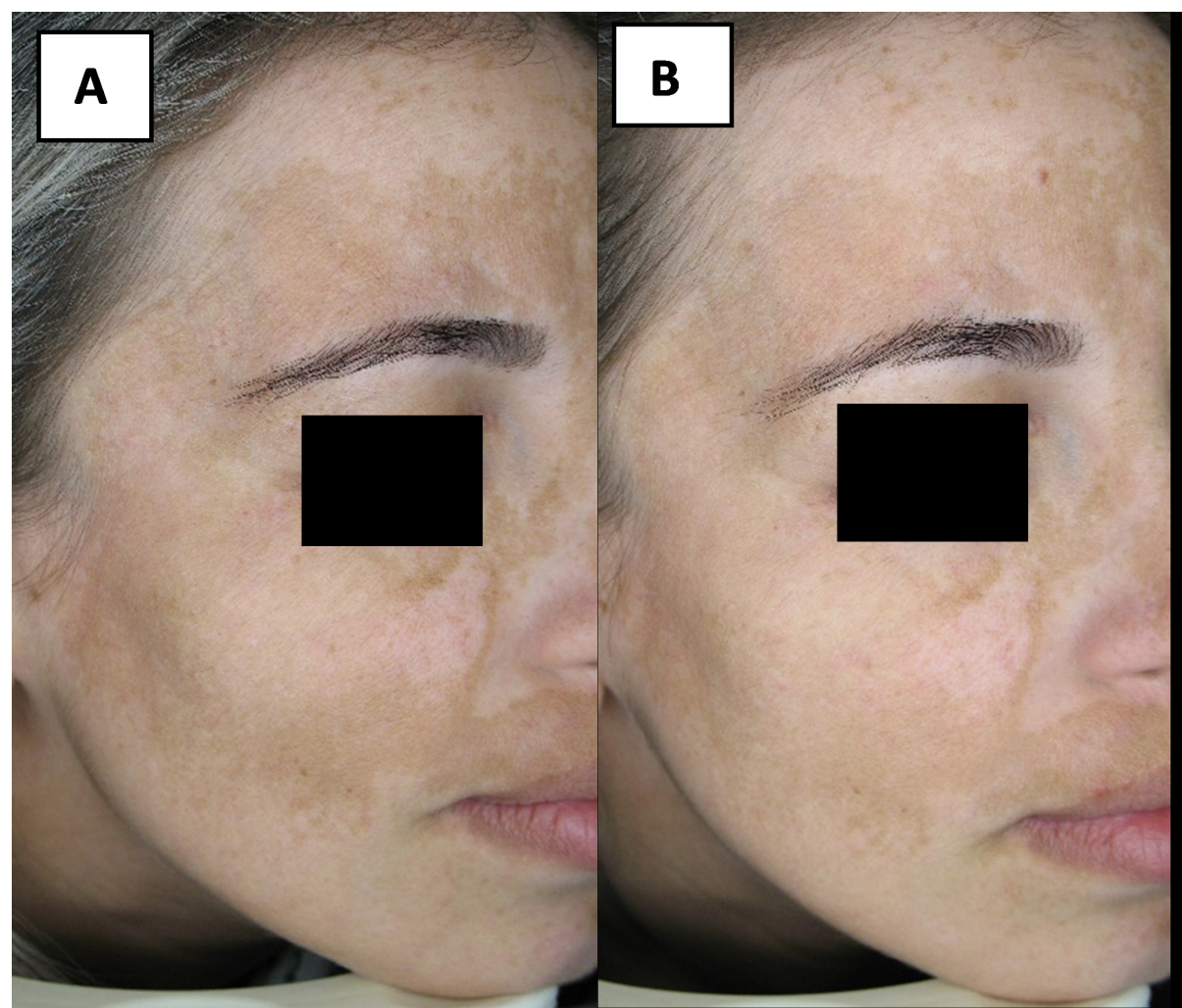

Figure 5 - A 38 year-old woman with recalcitrant melasma for 2 years before treatment (A) and after (B) 60 days of placebo use

Figura 5 - Participante de 38 anos com melasma recalcitrante por 2 anos antes do tratamento (A) e após (B) 60 dias de uso de placebo 


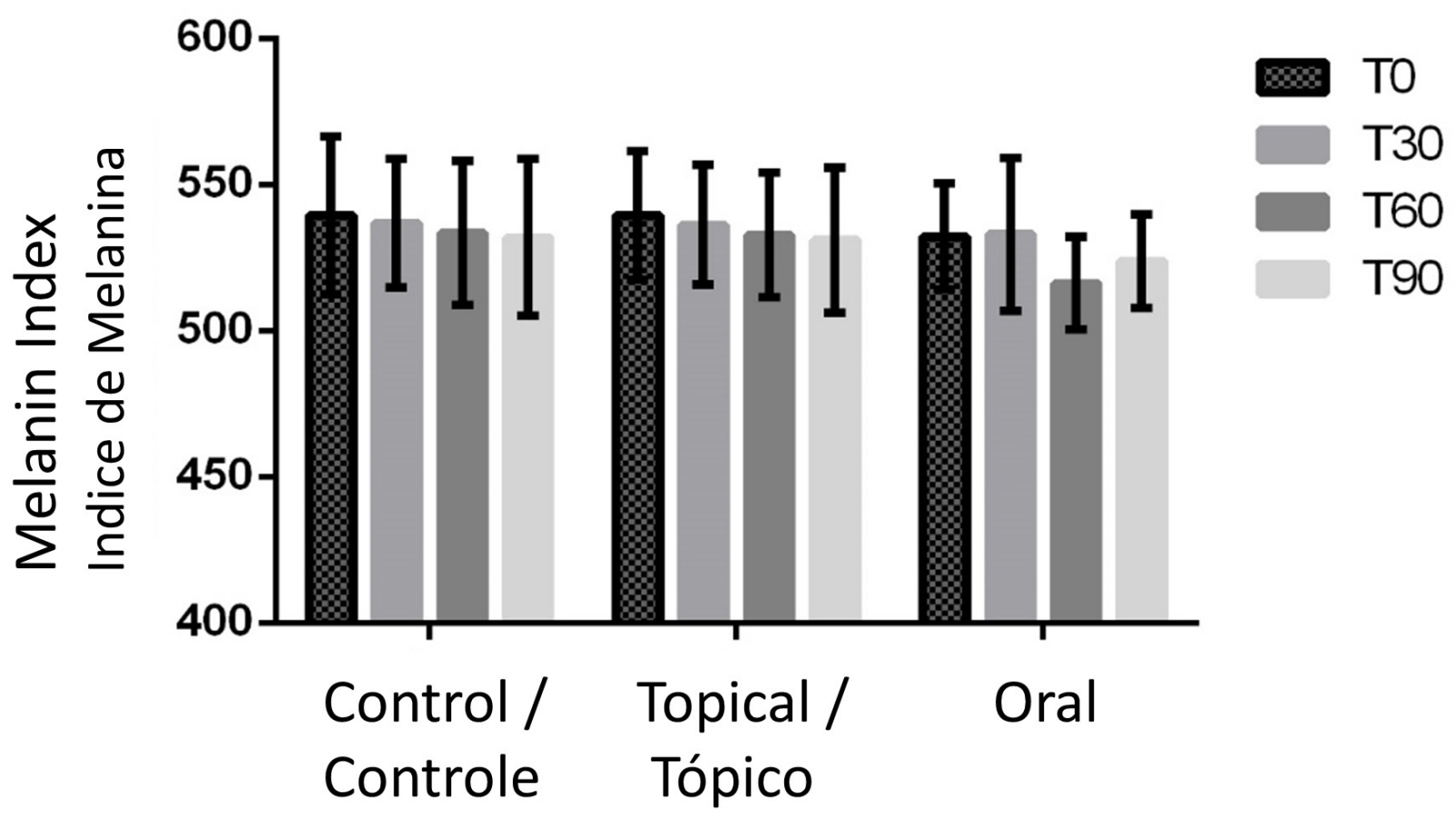

Figure 6 - Melanin index among treatment groups at evaluated times (means and confidence intervals CI95\% are indicated)

Figura 6 - Índice de melanina entre os grupos de tratamento nos tempos avaliados (são mostrados médias e intervalos de confiança IC95\%)

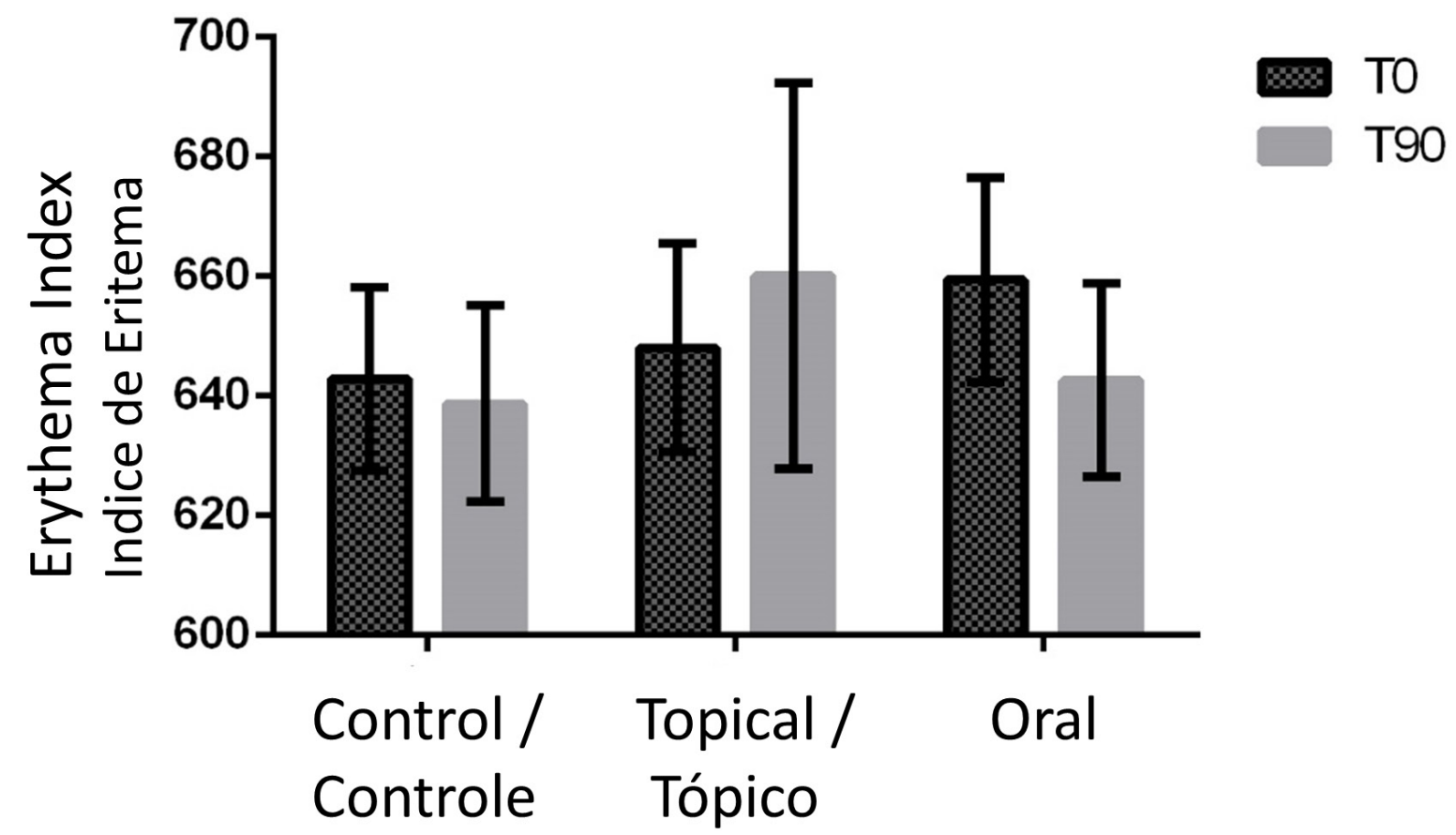

Figure 7 - Erythema index among treatment groups at evaluated times (means and confidence intervals CI95\% are indicated)

Figura 7 - Índice de eritema entre os grupos de tratamento nos tempos avaliados (são mostrados médias e intervalos de confiança IC95\%) 


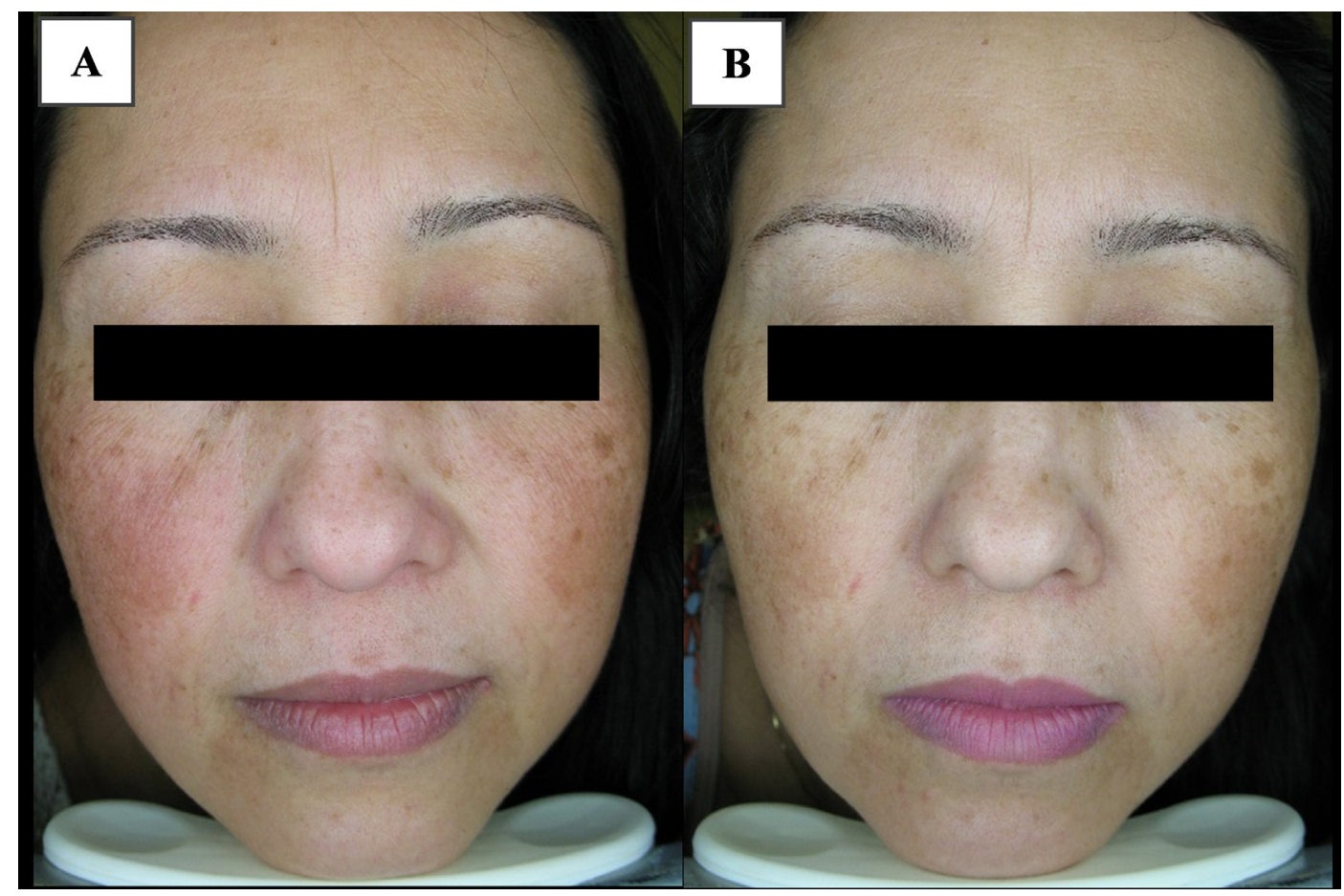

Figure 8 - A 36 year-old woman with erythema before treatment (A) and after 60 days (B) of the oral treatment containing the olive extract

Figura 8 - Participante de 36 anos com eritema antes (A) e após 60 dias (B) do tratamento oral contendo o extrato de oliva

in mMASI (Figure 6). However, significant results were detected in the melanin index when paired values for time variation in the oral group were analyzed individually as a single-arm (ANOVA RM, $\mathrm{p}=0.0466$ ) comparing the initial time with 60 days $(\mathrm{p}=0.0167)$ in multiple comparisons.

The Mexameter also provides erythema quantification related to vascular feature of melasma. The baseline values had no significant differences (ANOVA, $\mathrm{p}=0.277)$. Despite no significant difference between the treatments after 90 days (ANOVA, $\mathrm{p}=0.290$ ), the oral group showed higher decrease in erythema compared to the other groups (Figure 7). Figure 8 shows the image of a study participant with a reduction in erythema after 60 days of oral treatment. em todos os tempos avaliados (ANOVA, p $>0,05$ ), assim como observado no mMASI (Figura 6). No entanto, resultados significativos foram detectados no índice de melanina quando os valores pareados para variação de tempo no grupo oral analisado individualmente (ANOVA RM, $p=0,0466$ ) ao comparar o tempo inicial com 60 dias $(\mathrm{p}=0,0167)$

O Mexameter também fornece quantificação de eritema que está relacionada à característica de aumento da vascularização do melasma. Os valores de eritema iniciais não apresentaram diferenças significativas entre os grupos (ANOVA, $p=0,277$ ). Apesar de não haver diferença significativa entre os tratamentos após 90 dias (ANOVA, $\mathrm{p}=0,290$ ), o grupo oral apresentou maior diminuição do eritema em relação aos demais grupos (Figura 7). A Figura 8 mostra a imagem de uma participante com a redução no eritema após 60 dias do tratamento oral. 


\section{Discussion}

Corresponding to the results obtained in epidemiologic studies by Handel at al. and Tamega et al. $(25,26)$, the semi-structured interviews allowed the participants to report the most common triggering factor for melasma: solar radiation and hormonal alterations, including pregnancy or contraceptive use.

The demand for an effective treatment for melasma can be recognized by its chronic and relapsing characteristics, observed in this study as most of the participants had presented with the disorder for more than five years, and $71 \%$ had previously tried classical dermatodrlogical treatments containing hydroquinone. None of the patients had the melasma onset at less than 1 year. In addition, the dropout rate was equal in all groups and most occurred before 30 days of treatment. The period recommended for the first visual clinical affects for melasma is in 56 days (27).

In 2014, Jutley et al. performed a systematic review of melasma treatments, and determined the main limitation of the studies evaluated was poor methodology, with a lack of standardized outcome assessments (28). Therefore, to complement the subjective evaluation using mMASI score, the use of objective biophysical techniques is important for reproducible analysis in melasma clinical trials (29).

Despite the fact that no statistically significant alterations were observed in the mMASI scores, a reduction in all groups over time was observed, with a more pronounced pigmentation decrease after the oral treatment. Evaluating time as the main variable, in a singlearm or intragroup evaluation, the oral group presented significant reduction in mMASI when baseline values were compared to those after 60 and 90 days of treatment. It is important to emphasize that no reduction in melasma area parameter was observed in mMASI evaluation. Therefore, only pigmentation darkness showed decreased values in the score.

By the objective techniques, the melanin content presented similar results to mMASI, since no statistical difference was observed among treatment groups compared to the control at the evaluated times. However, a significant pigmentation decrease was noticed in the oral group when ANOVA RM was performed comparing 60 days to baseline, as a single-arm treatment.

The obtained results of the groups containing the olive extract compared to the control could indicate that hydroxytyrosol bioavailability at the basal layer of epidermis, where melanogenesis predominantly occurs, may have been lower than expected to exert its enzymatic competitive inhibition to tyrosinase in both oral

\section{Discussão}

Concordando com os resultados obtidos nos estudos epidemiológicos de Handel et al. e Tamega et al. $(25,26)$, as entrevistas semiestruturadas permitiram aos participantes relatar os fatores desencadeantes mais comuns do melasma, em suas concepções: radiação solar e alterações hormonais, incluindo gravidez ou uso de contraceptivos.

A demanda por um tratamento efetivo para o melasma pode ser reconhecida por suas características crônicas e recidivantes, que foram observadas à maioria das participantes apresentarem a doença por mais de 5 anos e $71 \%$ já haviam experimentado o tratamento dermatológico clássico contendo hidroquinona. Nenhuma das pacientes tivera o início do melasma em menos de 1 ano. Além disso, a taxa de abandono foi igual em todos os grupos e ocorreu principalmente antes de 30 dias de tratamento. No entanto, o período recomendado para os primeiros efeitos clínicos visuais para o melasma é de 56 dias (27).

Em 2014, Jutley et al. realizaram uma revisão sistemática dos tratamentos com melasma e a principal limitação dos estudos avaliados foram que as metodologias usadas eram inadequadas, levando ao lapso de avaliações padronizadas dos resultados (28). Então, para complementar a avaliação subjetiva do pesquisador usando o escore mMASI, o uso de técnicas biofísicas objetivas são importantes para a análise reprodutível nos estudo $\mathrm{s}$ clínicos de melasma (27).

Apesar de não terem sido observadas alterações estatisticamente significantes no escore do mMASI, foi observada redução em todos os grupos ao longo do tempo, com diminuição da pigmentação mais pronunciada após o tratamento oral. Avaliando o tempo como a variável principal, em uma avaliação intragrupo ou single arm, o grupo oral apresentou redução significativa no mMASI quando os valores basais foram comparados àqueles após 60 e 90 dias de tratamento. É importante enfatizar que nenhuma redução no parâmetro da área do melasma foi observada na avaliação do mMASI. Portanto, apenas o parâmetro da escuridão da pigmentação apresentou valores reduzidos na pontuação.

Pelas medidas objetivas realizadas, o índice de melanina apresentou resultados semelhantes ao mMASI, uma vez que não houve diferença estatística entre os grupos de tratamento em relação ao controle nos tempos avaliados. No entanto, uma diminuição significativa da pigmentação foi notada no grupo oral quando ANOVA RM foi realizada individualmente neste grupo comparando o tempo de 60 dias com o inicial. 
and topical pathways. Both olive extracts used in the study had a standardized concentration of hydroxytyrosol: $3 \%$ in the oral and $20 \%$ in the topical. Even so, the topical cream containing $1 \%$ of the olive extract was the maximum recommended by the distributor. Hence, Alonso et al. showed that the in vitro hydroxytyrosol epidermal absorption profile have presented a low skin penetration through the stratum corneum and reduced skin permeation to dermis (29). This could be improved by the conversion of hydroxytyrosol into more lipophilic hydroxytyrosol esters.

Despite the wide distribution of hydroxytyrosol to all tissues, its bioavailability by the oral route is also poor, as only $2 \%$ of the free form can be found at plasma after its intake (11). Even so, the higher depigmenting effect observed in the oral treatments compared to topical could suggest that the oral treatment dosage of this substance may attain a major bioavailability at the target site (epidermal basal layer) when compared to the topical delivery in this study.

So, further studies with higher concentrations of hydroxytyrosol from olive extracts for topical and oral routes are suggested to verify its depigmenting potential.

It was possible to observe reduction of the erythema in the oral group, despite not being significant. This effect can be a result of the great anti-inflammatory activity of the hydroxytyrosol, which in vitro studies presents a reduced pro-inflammatory cytokines and inducible nitric oxide synthase (iNOS) (30), which are involved in the increased vascular component in the lesion $(31,6)$. As melasma presents with an increased vascular component in lesional skin associatedwith photoaging $(32,5)$, erythema analysis was useful to assess the treatment response.

It is known that the therapies for melasma must not only target the tyrosinase inhibition but should have an anti-aging and anti-inflammatory approach $(5,6)$. Hydroxytyrosol is a single agent that has multiple potential mechanisms to support restoring the basal membrane, acting against cytokines and other inflammatory factors, inhibiting tyrosinase and exerting potent antioxidant activity, as previously described. As a result, other studies with higher concentrations of hydroxytyrosol contained in olive extracts have great potential to assist as an adjunct to conventional dermatological melasma therapy or as a complementary long-term maintenance treatment for melasma.
Os resultados obtidos nos grupos contendo o extrato de oliva comparados ao controle podem indicar que a biodisponibilidade do hidroxitirosol na camada basal da epiderme, onde a melanogênese ocorre predominantemente, pode ter sido menor do que o esperado para exercer sua inibição competitiva enzimática na tirosinase tanto oral quanto tópica. caminhos. Ambos os extratos de oliva utilizados no estudo tinham uma concentração padronizada de hidroxitirosol: $3 \%$ na oral e $20 \%$ na tópica. Mesmo assim, o creme tópico contendo $1 \%$ deste extrato de oliva foi o máximo recomendado pelo distribuidor. Além disso, Alonso et al. mostraram que o perfil de absorção epidérmica de hidroxitirosol in vitro apresentou baixa penetração cutânea através do estrato córneo e permeação cutânea reduzida à derme (29). Isto poderia ser melhorado pela conversão do hidroxitirosol em tensoativos derivados de éster para aumentar a sua lipofilicidade.

Apesar de o hidroxitirosol apresentar ampla distribuição para todos os tecidos, sua biodisponibilidade por via oral também é baixa, apenas $2 \%$ da forma livre pode ser encontrada no plasma após sua ingestão (11). Mesmo assim, o maior efeito de despigmentação observado nos tratamentos orais em comparação com o tópico poderia sugerir que a dosagem do tratamento oral dessa substância pode atingir uma biodisponibilidade maior no local alvo (camada basal epidérmica) quando comparado ao tópico neste estudo. Assim, estudos posteriores com maiores concentrações de hidroxitirosol a partir de extratos de oliva para rotas tópicas e orais são sugeridos para verificar seu potencial despigmentante. Foi possível observar redução do eritema no grupo oral, apesar de não significativa. Esse efeito pode ser resultado da grande atividade anti-inflamatória do hidroxitirosol que, em estudos in vitro, mostrou redução das citocinas pró-inflamatórias e a sintase induzida do óxido nítrico (iNOS) (30), que estão envolvidas no aumento do componente vascular na lesão $(31,6)$. Como o melasma apresenta aumento do componente vascular associada ao fotoenvelhecimento $(32,5)$, a análise do eritema foi interessante para avaliar essa resposta ao tratamento.

As terapias para o melasma não devem apenas visar a inibição da tirosinase, mas também devem ter uma abordagem antienvelhecimento e anti-inflamatória $(5,6)$. Assim, o hidroxitirosol é um agente único que possui múltiplos mecanismos potenciais para restaurar a membrana basal, atuar contra citocinas e outros fatores inflamatórios, inibir a tirosinase e exercer uma atividade antioxidante potente, como descritas anteriormente. Assim, o extrato de oliva com concentração padronizada de hidroxitirosol tem um grande potencial 


\section{Conclusion}

Considering the great interindividual variability that is an intrinsic melasma characteristic, the subjective and objective analysis showed no significant difference in the groups along time for the oral and topical treatment with the olive extract containing standardized concentration of hydroxytyrosol compared to placebo. However, the oral treatment reduced the mMASI and melanin index values after the 60 day usage period when compared to baseline values in intragroup analysis.

In addition, considering the described benefits, we suggest that further studies to test if an increased concentration of hydroxytyrosol could determine better results in the oral and topical treatments for melasma control.

Finally, this study contributes to better understanding of oral and topical treatments containing an ingredient with multiple beneficial pharmacological effects that presents great potential as an adjunctive to dermatological treatments for melasma control.

\section{Acknowledgements}

This study was financed by Coordenação de Aperfeiçoamento de Pessoal de Nível Superior - CAPES (Financial Code 001) and Conselho Nacional de Desenvolvimento Científico e Tecnológico - CNPq.

\section{Conflicts of interest}

The senior editor co-authoring this manuscript had no participation in the review nor in the decision process.

All authors have declared there were no financial and/ or personal relationships that may present a potential conflict of interest.

\section{Authors Contributions}

JB collected data and contributed to writing; EB was responsible for clinical evaluation and supervision and result analysis; PMC coordinated the study, including conceptual design, writing and final revision. para auxiliar como adjuvante à terapia dermatológica convencional do melasma ou como um tratamento complementar de manutenção de longo prazo pós-terapêutico para o melasma.

\section{Conclusão}

Considerando a grande variabilidade interindividual característica do melasma intrínseco, a análise subjetiva e objetiva não mostrou diferença significativa nos grupos ao longo do tempo para o tratamento oral e tópico com o extrato de oliva contendo concentração padronizada de hidroxitirosol comparado ao placebo. No entanto, o tratamento oral reduziu os valores do índice mMASI e melanina após 60 dias, quando comparado com os valores basais na análise intragrupo.

Além disso, considerando os benefícios descritos do extrato de oliva, sugere-se que novos estudos verifiquem se maiores concentração de hidroxitirosol poderia determinar melhores resultados nos tratamentos orais e tópicos para o controle do melasma.

Finalmente, este estudo contribui para uma melhor compreensão dos tratamentos orais e tópicos com um ingrediente com múltiplos efeitos farmacológicos benéficos de fontes naturais que apresentam grande potencial como adjuvante aos tratamentos dermatológicos para o controle do melasma.

\section{Agradecimentos}

Este estudo foi financiado pela Coordenação de Aperfeiçoamento de Pessoal de Nível Superior - CAPES (Financial Code 001) e pelo Conselho Nacional de Desenvolvimento Científico e Tecnológico - CNPq.

\section{Conflitos de interesse}

O editor senior envolvido na autoria deste manuscrito não teve qualquer participação no processo de revisão ou de decisão.

Todos os autores declararam não haver relações financeiras e/ou pessoais que possam representar um potencial conflito de interesses.

\section{Contribuições dos Autores}

JB coletou dados e contribuiu com a redação; EB foi responsável pela avaliação clínica, supervisão e análise de resultados; PMC coordenou o estudo, incluindo o desenho conceptual, redação e revisão final. 


\section{References / Referências}

1. Handel AC, Miot LDB, Miot HA. Melasma: a clinical and epidemiological review. An Bras Dermatol 2014; 89(5):771-82.

2. Ortonne JP, Arellano I, Berneburg M, et al. A global survey of the role of ultraviolet radiation and hormonal influences in the development of melasma. J Eur Acad Dermatol Venereol 2009; 23:1254-62.

3. Hexsel D, Lacerda DA, Cavalcante AS, et al . Epidemiology of melasma in B razilian patients: a multicenter study. Int J Dermatol 2014; 53(4): 440-444.

4. Ikino JK, Nunes DH, da Silva VPM, et al. Melasma and assessment of the quality of life in Brazilian women. An Bras Dermatol 2015; 90(2):196-200.

5. Passeron T, Picardo M. Melasma, a photoaging disorder. Pigment Cell Melanoma Res 2018; 31(4):461-465.

6. Kwon SH, Hwang YJ, Lee SK, Park KC. Heterogeneous pathology of melasma and its clinical implications. Int J Mol Sci 2016; $17(6): 824$.

7. Miot LDB, Miot HA, Silva MG, Marques MEA. Physiopathology of melasma. An Bras Dermatol 2009; 84(6):623-35.

8. Lee SY, Baek N, Nam T. Natural, semisynthetic and synthetic tyrosinase inhibitors. J Enzyme Inhib Med Chem 2016; 31(1):1-13.

9. Khan M. Novel tyrosinase inhibitors from natural resources-their computational studies. Curr Med Chem 2012; 19(14):2262-2272.

10. Chang TS. An updated review of tyrosinase inhibitors. Int J Mol Sci 2009; 10(6):2440- 2475.

11. Robles-Almazan M, Pulido-Moran M, Moreno-Fernandez J, et al. Hydroxytyrosol: Bioavailability, toxicity, and clinical applications. Food Res Int 2017; 105:654-667.

12. Hu T, He XW, Jiang JG, Xu XL. Hydroxytyrosol and its potential therapeutic effects. J Agric Food Chem 2014; 62(7):1449-1455.

13. Visioli F, Bellomo G, Galli C. Free radical-scavenging properties of olive oil polyphenols. Biochem Biophys Res Commun 1998; $247(1): 60-64$.

14. Rodrigues M, Pandya AG. Melasma: clinical diagnosis and management options. Australas J Dermatol 2015; 56(3):151-163.

15. Lee, A. Recent progress in melasma pathogenesis. Pigment Cell Melanoma Res. 2015; 28(6): 648-660.

16. Scoditti E, Nestola A, Massaro M, et al. Hydroxytyrosol suppresses MMP-9 and COX-2 activity and expression in activated human monocytes via PKCalpha and PKCbeta1 inhibition. Atherosclerosis 2014; 232(1):17-24.

17. Torres-Alvarez B, Mesa-Garza IG, Castanedo-Cazares JP, et al. Histochemical and immunohistochemical study in melasma: evidence of damage in the basal membrane. Am J Dermatopathol 2011; 33:291-5.

18. Fitzpatrick T. B. The validity and practicality of sun-reactive skin types I through VI. Arch Dermatol 1988; 124 (6):869-871.

19. Urbaniak, G. C., \& Plous, S. (2015). Research Randomizer (Version 4.0) [Computer software]. Retrieved on May 2017, from http://www.randomizer.org/

20. Pandya AG, Hynan LS, Bhore R, et al. Reliability assessment and validation of the Melasma Area and Severity Index (MASI) and a new modified MASI scoring method. J Am Acad Dermatol 2011; 64:78-83.

21. Uchida R, Ishikawa S, Tomoda H. Inhibition of tyrosinase activity and melanine pigmentation by 2-hydroxytyrosol. Acta Pharm Sin B 2014, 4:141-5.

22. Guo, W, An Y, Jiang L, Geng C, Zhong L. The protective effects of hydroxytyrosol against UVB-induced DNA damage in HaCaT cells. Phytother Res 2010; 24(3):352-359.

23. Zwane RE, Parker A, Kudanga T, et al. Novel biocatalytically produced hydroxytyrosol dimer protects against ultraviolet-induced cell death in human immortalized keratinocytes. J Agric Food Chem 2012; 60(46):11509-11517.

24. Salucci S, Burattini S, Curzi D, et al. Antioxidants in the prevention of UVB-induced keratinocyte apoptosis. J Photochem Photobiol B. 2014; 141:1-9.

25. Handel AC, Miot LDB, Miot HA. Melasma: a clinical and epidemiological review. An Bras Dermatol 2014; 89(5):771-82.

26. Tamega A, Miot LDB, Bonfietti C, et al. Clinical patterns and epidemiological characteristics of facial melasma in Brazilian women. J Eur Acad Dermatol Venereol. 2013; 27:151-6.

27. Pandya A, Berneburg M, Ortonne JP, Picardo M. Guidelines for clinical trials in melasma. Pigmentation Disorders Academy. Br J Dermatol 2016, 156 (1):21-8.

28. Jutley G, Rajaratnam R, Halpern J, et al. Systematic review of randomized controlled trials on interventions for melasma: an abridged Cochrane review. J Am Acad Dermatol. 2014; 70(2):369-73.

29. Alonso C, Lucas R, Barba C, et al. Skin delivery of antioxidant surfactants based on gallic acid and hydroxytyrosol. J Pharm Pharmacol 2016; 67(7):900-908.

30. Zhang X, Cao J, Zhong L. Hydroxytyrosol inhibits pro-inflammatory cytokines iNOS and COX-2 expression in human monocytic cells. Naunyn Schmiedebergs Arch Pharmacol 2009; 379(6):581-586.

31. Jo HY, Kim CK, Suh IB, et al. Co-localization of inducible nitric oxide synthase and phosphorylated Akt in the lesional skins of patients with melasma. J. Dermatol. 2009; 36:10-16.

32. Na JI, Choi SY, Yang SH, et al. Effect of tranexamic acid on melasma: a clinical trial with histological evaluation. J Eur Acad Dermatol Venereol 2013; 27(8):1035-9. 